\title{
Regulation of glycolysis/fructolysis in buffalo spermatozoa
}

\author{
K. K. Gandhi and S. R. Anand \\ National Dairy Research Institute, Karnal-132001, India
}

\begin{abstract}
Summary. Assay of maximal activities of 11 glycolytic enzymes in cell-free buffalo sperm extracts showed that hexokinase, phosphofructokinase and glyceraldehyde3-phosphate dehydrogenase had the lowest activities, suggesting regulation of fructolysis at steps catalysed by these enzymes. The ratios of glyceraldehyde3-phosphate dehydrogenase/phosphofructokinase $(0.67)$ and phosphoglycerate kinase/phosphofructokinase (4.60) are typical of cells exhibiting high Pasteur effect (50\% for ejaculated buffalo spermatozoa). The regulatory nature of phosphofructokinase was shown through its modulation by ATP, AMP and inorganic phosphate. The determination of fructolytic intermediates and cofactors and calculation of mass action ratios for each enzymic step revealed that hexokinase, phosphofructokinase, fructose-biphosphate aldolase, glyceraldehyde-3-phosphate dehydrogenase and pyruvate kinase catalysed reactions far removed from the equilibrium. A regulatory role by glyceraldehyde-3-phosphate dehydrogenase appeared to be most likely because triosephosphates and inorganic phosphate accumulated more under anaerobic than under aerobic conditions.
\end{abstract}

\section{Introduction}

Experimental approaches to identify regulatory enzymes include assay of maximal enzyme activities in vitro, determination of rates of product formation from various precursors and intermediates, description of the kinetics and allosteric properties of isolated enzymes and measurements of the effects of altered flux rates on the tissue content of pathway intermediates (Newsholme \& Gevers, 1967). The regulation of glycolysis/fructolysis in human (Peterson \& Freund, 1970, 1971), rhesus monkey (Hoskins, Stephens \& Casillas, 1971) and bovine (Hoskins, 1973) spermatozoa has been studied by one or more approaches to locate possible control points. By employing three different experimental approaches as listed above, we have studied glycolysis/fructolysis in buffalo spermatozoa.

\section{Materials and Methods}

Triethanolamine chloride, Tris, pyrophosphate buffer, sodium pyruvate, NAD, NADH, ATP, ADP, AMP, 2-mercaptoethanol, dithiothreitol, EDTA, fructose 6-phosphate, fructose 1,6diphosphate, glyceraldehyde-3-phosphate, 3-phosphoglyceric acid, 2-phosphoglyceric acid, 2,3-diphosphoglycerate, DL-3-phosphoglyceric acid, phosphoenolpyruvate, pyruvic acid, dihydroxyacetone phosphate and glycylglycine were purchased from Sigma Chemical Co., St Louis, Missouri, U.S.A. The following enzymes were also purchased from Sigma: hexokinase 
(EC 2.7.1.1), lactate dehydrogenase (EC 1.1.1.28) pyruvate kinase (EC 2.7.1.40), phosphoglyceromutase (EC 2.7.5.3), glucosephosphate isomerase (EC 5.3.1.9), glycerol3-phosphate dehydrogenase (EC 1.1.1.8), enolase (EC 4.2.1.11), fructose-biphosphate aldolase (EC 4.1.2.13), adenylate kinase (EC 2.7.4.3), glyceraldehyde-3-phosphate dehydrogenase (EC 1.2.1.12), triosephosphate isomerase (EC 5.3.1.1). All other chemicals were of analytical reagent grade.

\section{Collection and washing of semen}

Semen was collected from Murrah buffalo bulls (Bubalus bubalis) by using an artificial vagina. Pooled samples from at least 2 bulls having good initial sperm motility (at least 4 on a 5 -point scale) were used. Sperm counts were made in duplicate with a haemocytometer. The semen was washed by dilution with Krebs-Ringer solution to free it from seminal plasma and incubated in a Warburg apparatus under aerobic and anaerobic conditions as previously described (Gandhi \& Anand, 1975).

\section{Preparation of cell free extract}

Freshly obtained pooled semen was washed with $0.25 \mathrm{M}$-mannitol and then suspended in 0.1 M-Tris- $\mathrm{HCl}$ buffer, $\mathrm{pH} \mathrm{7.4}$. The suspension was chilled and sonicated for $1 \mathrm{~min}$ at a time for a total of $3 \mathrm{~min}$ in a Branson Sonifier Model B-12. The sonicated suspension was first centrifuged in a refrigerated centrifuge and then in an ultracentrifuge at $100000 \mathrm{~g}$ for $1 \mathrm{~h}$.

\section{Estimation of glycolytic intermediates and coenzymes}

Semen washed free of seminal plasma was suspended in Krebs-Ringer phosphate buffer, $\mathrm{pH}$ 7.4 and then shaken in Warburg flasks for $30 \mathrm{~min}$. The metabolism was stopped by injection of an equal volume of ice-cold $20 \%$ perchloric acid. The sperm suspension was kept in ice for 60 min and then was centrifuged for $15 \mathrm{~min}$ at $20000 \mathrm{~g}$. The supernatant was neutralized to $\mathrm{pH} 7.0$ by slow addition of solid potassium carbonate with constant mixing. After keeping in ice for 30 min, the tubes were centrifuged and the supernatant was used for the assay of intermediates. All the glycolytic intermediates were assayed spectrophotometrically by standard assays (Bergmeyer, 1963). Adenine nucleotides were also estimated by spectrophotometric methods as described by Adam (1963a, b).

\section{Assay of glycolytic enzymes}

The individual glycolytic enzymes in the cell-free buffalo sperm extract were estimated spectrophotometrically by measuring the changes in concentration of reduced or oxidized pyridine nucleotides which served either as coenzyme of the enzyme being assayed or of an auxiliary enzyme system coupled to the enzyme reaction under study. The following methods were used and the activities of the 11 enzymes measured are expressed as $\mu \mathrm{mol}$ substrate transformed into products per mg protein of enzyme extract. Hexokinase and glucosephosphate isomerase were assayed according to the procedure of Harrison \& White (1972). Fructosebiphosphate aldolase, 6-phosphofructokinase (EC 2.7.1.11), glyceraldehyde-phosphate dehydrogenase, phosphoglyceromutase and lactate dehydrogenase were assayed by the methods described by $\mathrm{Wu} \&$ Racker (1959). Triosephosphate isomerase was assayed according to Beisenherz (1955). Phosphoglycerate kinase (EC 2.7.2.3), enolase and pyruvate kinase were estimated by the method of Buchner (1955). 


\section{Analytical methods}

Protein was estimated by the method of Lowry, Rosebrough, Farr \& Randall (1951) using bovine serum albumin as the reference protein. Inorganic phosphorus was estimated according to the method of Fiske \& SubbaRow (1925). The Pasteur effect was calculated by the formula $100\left(Z_{L} N_{2}-Z_{L} O_{2}\right) / Z_{L} N_{2}$ where $Z_{L} N_{2}$ is the rate of lactic acid formation $\left(\mu \mathrm{mol} / \mathrm{h} / 10^{8}\right.$ spermatozoa) when $\mathrm{N}_{2}$ is the gas phase and $\mathrm{Z}_{\mathrm{L}} \mathrm{O}_{2}$ is the rate of lactic acid formation when air or $\mathrm{O}_{2}$ is the gas phase. Calculations were made from data of Text-fig. 1 of our earlier paper (Gandhi \& Anand, 1975).

\section{Results}

In-vitro assay of glycolytic enzymes

Cell-free extracts of buffalo spermatozoa supplemented with $0.67 \mathrm{mM}-\mathrm{NAD}$ and $1 \mathrm{mM}-\mathrm{ATP}$ were incubated with fructose at initial concentrations ranging between 2.5 and $11 \mathrm{mg} / \mathrm{ml}$. The rates were measured by estimating the disappearance of fructose or the formation of lactic acid. Previous incubations of washed buffalo spermatozoa with fructose under anaerobic and aerobic conditions (Gandhi \& Anand, 1975) showed that fructose content was increased by the 2nd hour of incubation. In the present experiments with the cell-free extracts, the increase in fructose content over the initial fructose used became evident at the 1st hour of incubation. The results suggest that the oxidation and synthesis of fructose occurred simultaneously and that the rates for both processes were not linear in relation to time of incubation or protein concentration (1-8 $\mathrm{mg} / \mathrm{ml})$.

The results for 11 glycolytic enzymes are presented in Table 1. Lactate dehydrogenase had the highest activity, hexokinase, phosphofructokinase and glyceraldehyde-3-phosphate dehydro-

Table 1. Activities of glycolytic enzymes in cell-free extracts of buffalo spermatozoa

\begin{tabular}{|c|c|c|}
\hline \multirow[b]{2}{*}{ Enzyme } & \multicolumn{2}{|c|}{ Activity } \\
\hline & $\begin{array}{c}\mu \mathrm{mol} / \mathrm{h} \text { per } \\
10^{8} \text { spermatozoa }\end{array}$ & $\begin{array}{l}\mu \mathrm{mol} / \mathrm{h} \text { per } \\
\mathrm{mg} \text { protein }\end{array}$ \\
\hline $\begin{array}{l}\text { Hexokinase } \\
\quad(\text { EC 2.7.1.1) }\end{array}$ & $2 \cdot 8 \pm 0.23$ & $0.94 \pm 0.10$ \\
\hline $\begin{array}{l}\text { Glucosephosphate isomerase } \\
\text { (EC 5.3.1.9) }\end{array}$ & $16 \cdot 31 \pm 1 \cdot 86$ & $5 \cdot 32 \pm 0 \cdot 43$ \\
\hline $\begin{array}{l}\text { Phosphofructokinase } \\
\text { (EC 2.7.1.11) }\end{array}$ & $2 \cdot 23 \pm 0.17$ & $0.74 \pm 0.41$ \\
\hline $\begin{array}{l}\text { Fructose-biphosphate aldolase } \\
\text { (EC 4.1.2.13) }\end{array}$ & $7 \cdot 60 \pm 0 \cdot 31$ & $2.50 \pm 0.05$ \\
\hline $\begin{array}{l}\text { Triosephosphate isomerase } \\
\text { (EC 5.3.1.1) }\end{array}$ & $10.67 \pm 0.19$ & $3.53 \pm 0.13$ \\
\hline $\begin{array}{l}\text { Glyceraldehyde-3-phosphate dehydrogenase } \\
\text { (EC 1.2.1.12) }\end{array}$ & $1.46 \pm 0 \cdot 19$ & $0.49 \pm 0.03$ \\
\hline $\begin{array}{l}\text { Phosphoglycerate kinase } \\
\text { (EC 2.7.2.3) }\end{array}$ & $10.22 \pm 0.56$ & $3 \cdot 36 \pm 0 \cdot 39$ \\
\hline $\begin{array}{l}\text { Phosphoglyceromutase } \\
\text { (EC 2.7.5.3) }\end{array}$ & $3.40 \pm 0.23$ & $1 \cdot 20 \pm 0 \cdot 12$ \\
\hline $\begin{array}{l}\text { Enolase } \\
\quad(E C \text { 4.2.1.11) }\end{array}$ & $3.91 \pm 0.21$ & $1.29 \pm 0.03$ \\
\hline $\begin{array}{l}\text { Pyruvate kinase } \\
\text { (EC 2.7.1.40) }\end{array}$ & $8.60 \pm 0.47$ & $2.83 \pm 0.03$ \\
\hline $\begin{array}{l}\text { Lactate dehydrogenase } \\
\text { (EC 1.1.1.28) }\end{array}$ & $100 \cdot 36 \pm 2 \cdot 33$ & $33 \cdot 12 \pm 0.99$ \\
\hline
\end{tabular}


genase had the lowest activities and the rest were intermediate. Nevertheless, the activity of each of these enzymes given in Table 1 exceeded the rate of lactic acid formation $\left(0.7 \mu \mathrm{mol} \mathrm{h}^{-1} \mathrm{mg}\right.$ protein $^{-1}$ ) in the intact sperm cell.

\section{Allosteric properties of buffalo sperm phosphofructokinase}

Phosphofructokinase is known to regulate glycolysis. It is inhibited by negative allosteric effectors such as ATP and citrate and activated by positive allosteric effectors such as AMP, 3'5'-cyclic AMP, ADP and inorganic phosphate. ATP increased the rate of conversion of fructose 6-phosphate to fructose 1,6-diphosphate by buffalo sperm phosphofructokinase up to concentrations of $1 \mathrm{mM}$ ( 20 to $30 \%$ from 0.1 to $1 \mathrm{mM}$ ) but higher concentrations were inhibitory (15-20\% at $3 \mathrm{~mm} ; 3$ exps, data not shown). The inhibition was removed by the addition of $1 \mathrm{mM}$-AMP or $10 \mathrm{mM}$-inorganic phosphate.

\section{Identification of non-equilibrium reactions in buffalo sperm glycolysis/fructolysis}

Further evidence about the enzymic steps at which glycolysis/fructolysis in buffalo sperm may be regulated was obtained by identifying the non-equilibrium reactions. The concentrations of fructolytic intermediates were determined in perchloric acid-extracts of washed buffalo spermatozoa incubated for $30 \mathrm{~min}$ under anaerobic and aerobic conditions. The profile of intermediates (Table 2) shows that there were appreciable differences in the amounts of triosephosphates and inorganic phosphate during aerobic and anaerobic fructolysis. Triosephosphates increased 2-3-fold and inorganic phosphate 5-fold more under anaerobic conditions. Inorganic phosphate is utilized in glycolysis for the conversion of glyceraldehyde-3-phosphate to 3-phosphoglyceric acid. An enzymic control by glyceraldehyde-3-phosphate dehydrogenase therefore appears to be a distinct possibility. This was also revealed by comparison of mass action ratios (Table 3) with the apparent equilibrium constants (Barman, 1969). The mass action ratios were calculated from the intermediate concentrations given in Table 2. For the conversion of glyceraldehyde-3-phosphate to 3-phosphoglyceric acid, combined equilibrium constants were

Table 2. Concentrations of glycolytic intermediates and cofactors in buffalo spermatozoa

\begin{tabular}{|c|c|c|}
\hline Intermediates* & $\begin{array}{c}\text { Aerobic } \\
\text { incubation } \\
\left(\mathrm{nmol} / 10^{8} \text { spermatozoa }\right)\end{array}$ & $\begin{array}{c}\text { Anaerobic } \\
\text { incubation } \\
\text { (nmol/108 spermatozoa) }\end{array}$ \\
\hline Glucose & $462.0(2)$ & $370 \cdot 0(2)$ \\
\hline Fructose & $957 \cdot 8(2)$ & $1223 \cdot 5(2)$ \\
\hline Glucose 6-phosphate & $6.36 \pm 2.84$ & $5 \cdot 38 \pm 2 \cdot 80$ \\
\hline Fructose 6-phosphate & $17 \cdot 84 \pm 11 \cdot 30$ & $13 \cdot 38 \pm 2 \cdot 80$ \\
\hline Fructose 1,6-diphosphate & $0.87 \pm 0.51$ & $0.90 \pm 0.54$ \\
\hline Dihydroxyacetone phosphate & $1.97 \pm 0.78$ & $3.55 \pm 1.70$ \\
\hline Glyceraldehyde-3-phosphate & $0.82 \pm 0.22$ & $2.57 \pm 0.58$ \\
\hline 3-Phosphoglyceric acid & $9.45 \pm 2.70$ & $5.22 \pm 2.83$ \\
\hline 2-Phosphoglyceric acid & $2.66 \pm 0.71$ & $3.67 \pm 1.35$ \\
\hline Phosphoenolpyruvic acid & $0.30 \pm 0.30$ & $0.20 \pm 0.20$ \\
\hline Pyruvate & $2.06 \pm 0.76$ & $2.52 \pm 0.79$ \\
\hline Lactate & $119.55 \pm 37.83$ & $159.90 \pm 50.95$ \\
\hline Orthophosphate & $34.40(\overline{2})$ & $169 \cdot 70(\overline{2})$ \\
\hline NAD/NADH & $510 \cdot 0$ & $450 \cdot 0$ \\
\hline ATP & $3 \cdot 30(2)$ & $5 \cdot 70(2)$ \\
\hline ADP & $1 \cdot 31(2)$ & $4 \cdot 50(2)$ \\
\hline AMP & $1.60(2)$ & $3 \cdot 0(2)$ \\
\hline
\end{tabular}

*Values are mean \pm s.e.m. for 5 samples analysed. For intermediates of which the mean was not found, the average of 2 experiments is given. 
used because 1,3-diphosphoglyceric acid was not estimated. Five of the enzymes, i.e. hexokinase, phosphofructokinase, fructose-biphosphate aldolase, glyceraldehyde-3-phosphate dehydrogenase and pyruvate kinase, catalysed reactions in buffalo spermatozoa far removed from equilibrium. Pyridine nucleotides (NAD, NADH) were not estimated but their ratio, NAD/NADH, was calculated from the concentrations of pyruvate and lactate shown in Table 2 and an assumed $\mathrm{K}_{\mathrm{eq}}$ for lactate dehydrogenase of $3 \times 10^{5} \mathrm{M}$.

Table 3. Comparison of mass action ratios with apparent equilibrium constants $\left(K_{\text {eq }}\right)$ for enzymic steps in buffalo sperm fructolysis

\begin{tabular}{llll}
\hline & & \multicolumn{2}{c}{ Mass-action ratio $\times \mathbf{M}$} \\
\cline { 4 - 4 } \multicolumn{1}{c}{ Enzyme reaction } & $\begin{array}{c}\text { Apparent } \\
K_{\text {eq }} \times \mathbf{M}^{*}\end{array}$ & Aerobic & Anaerobic \\
\hline Hexokinase & & & \\
$\quad$ Glucose as substrate & $6.3 \times 10^{3}$ & 0.064 & 0.044 \\
$\quad$ Fructose as substrate & $6.3 \times 10^{3}$ & 0.056 & 0.033 \\
Glucosephosphate isomerase & 0.4 & 2.80 & 2.48 \\
Phosphofructokinase & $1.2 \times 10^{3}$ & 0.15 & 0.20 \\
Fructose-biphosphate aldolase & $8.1 \times 10^{-5}$ & 18.62 & $0.1 \times 10^{3}$ \\
Triosephosphate isomerase & 22.0 & 2.39 & 0.72 \\
Glycerate phosphate dehydrogenase + & $3.0 \times 10^{3}$ & $1.6 \times 10^{-6}$ & $0.2 \times 10^{-6}$ \\
$\quad$ phosphoglycerate kinase & & & 0.70 \\
Phosphoglyceromutase & 6.2 & 0.35 & 0.07 \\
Enolase & 4.0 & 0.12 & 2.57 \\
Pyruvate kinase & $6.5 \times 10^{3}$ & 2.26 & \\
\hline
\end{tabular}

*Taken from Barman (1969).

\section{Discussion}

Assay of maximal enzyme activities in cell-free extracts of buffalo spermatozoa (Table 1) revealed three enzymes, hexokinase, phosphofructokinase and glyceraldehyde-3-phosphate dehydrogenase, with low activities which might serve as the possible control points in vivo. Although the amount of each of these enzymes was enough not to limit glycolysis/fructolysis, the reactions they catalysed could be rate limiting because of their modulation by coenzymes/cofactors. Hexokinase and phosphofructokinase require ATP as a cofactor while glyceraldehyde-3-phosphate dehydrogenase, the least active of the three enzymes, depends for its activity on NAD and inorganic phosphorus. In human spermatozoa examined for maximal enzyme activities of the glycolytic pathway, hexokinase and phosphofructokinase were found in the lowest concentrations, suggesting a regulatory role for the two enzymes (Peterson \& Freund, 1970). An additional site of enzymic regulation of glycolysis in human spermatozoa at the level of glyceraldehyde-3-phosphate dehydrogenase (Peterson \& Freund, 1971) was evident when the glycolytic intermediates were estimated in perchloric acid-extracts of washed spermatozoa. Determination of fructolytic intermediates and cofactors and the calculation of mass action ratios for each enzymic step for monkey spermatozoa (Hoskins et al., 1971) showed that the potential control in vivo occurs at the level of hexokinase, phosphofructokinase and pyruvate kinase. Similar studies of fructolytic intermediates in buffalo spermatozoa (Table 2) and correlation of mass action ratios (Table 3) revealed 5 enzymic steps, catalysed by hexokinase, phosphofructokinase, fructose-biphosphate aldolase, glyceraldehyde-3-phosphate dehydrogenase and pyruvate kinase which were greatly disturbed from equilibrium and are therefore likely to be regulatory sites in vivo.

Although phosphofructokinase showed properties consistent with a regulatory role for fructolysis in buffalo spermatozoa, low ATP/ADP ratios and the accumulation of triose phosphate and fructose diphosphate in human spermatozoa incubated under anaerobic and 
aerobic conditions led Peterson \& Freund (1971) to suggest that phosphofructokinase may not be under appreciable inhibition. Similar conclusions were reached by Hoskins et al. (1971) based on $\mathrm{pH}$-induced changes in phosphofructokinase in monkey spermatozoa. In buffalo spermatozoa, the energy charge ratios $(0.63$ and 0.60 under aerobic and anaerobic fructolysis) indicate low ATP content which could also leave phosphofructokinase to remain uninhibited in this species. However, the regulation of glycolysis/fructolysis in buffalo spermatozoa may not be only under the control of the adenylate pool. Buffalo semen has a slightly acidic $\mathrm{pH}(6 \cdot 8)$ while in the oviducal fluid it is on the alkaline side $(\sim 8.0)$. A $40 \%$ increase in fructolysis rate was observed when buffalo spermatozoa were incubated at pH 7 and 8 (Gandhi \& Anand, 1975). In addition, ejaculated buffalo spermatozoa, under conditions of anaerobiasis, exhibit a significant increase in glycolytic rate. The Pasteur effect was calculated to be $50 \%$ which is high compared to that in human spermatozoa (2-10\%) reported by Peterson \& Freund (1971). The ratios of glyceraldehyde-3-phosphate dehydrogenase/phosphofructokinase $(0.67)$ and phosphoglycerate kinase/phosphofructokinase (4.60) in buffalo spermatozoa (Table 1) compare very well with those in mouse brain exhibiting a high Pasteur effect (Racker, 1965). Finally, inorganic phosphate $(5 \mathrm{~mm})$ substantially increases the glycolytic rate of washed buffalo spermatozoa (Gandhi \& Anand, 1975). The three factors ( $\mathrm{pH}$, Pasteur effect and $\mathbf{P}_{1}$ ) which increase fructolysis in buffalo spermatozoa, are being further studied to show how glycolysis/fructolysis is regulated.

This is NDRI publication No. 80-387.

\section{References}

Adam, H. (1963a) Adenosine 5'-triphosphate determination with phosphoglycerate kinase. In Methods of Enzymatic Analysis, pp. 539-543. Ed. H. U. Bergmeyer. Academic Press, New York.

Adam, H. (1963b) Adenosine $5^{\prime}$-diphosphate and adenosine 5'-monophosphate. In Methods of Enzymatic Analysis, pp. 573-577. Ed. H. U. Bergmeyer. Academic Press, New York.

Barman, T.E. (1969) The Enzyme Handbook, Vols 1 and 2. Springer, New York.

Beisenherz, G. (1955) Triosephosphate isomerase from calf muscle. Methods Enzymol. 1, 387-391.

Bergmeyer, H.U. (Ed.) (1963) Methods of Enzymatic Analysis. Academic Press, New York.

Buchner, T. (1955) Phosphoglycerate kinase from Brewers yeast. Methods Enzymol. 1, 415-422.

Fiske, C.H. \& SubbaRow, Y. (1925) The colorimetric determination of phosphorus. J. biol. Chem. 66, 375-385.

Gandhi, K.K. \& Anand, S.R. (1975) Fructolysis and respiration of buffalo spermatozoa. J. Reprod. Fert. 45, 185-188.

Harrison, R.A.P. \& White, I.G. (1972) Some methods of washing spermatozoa from bull, boar and ram. A comparison using biochemical and other criteria. $J$. Reprod. Fert. 29, 271-284.
Hoskins, D.D. (1973) Adenine nucleotide mediation of fructolysis and motility in bovine epididymal spermatozoa. J. biol. Chem. 248, 1135-1140.

Hoskins, D.D., Stephens, D.T. \& Casillas, E.R. (1971) Enzymatic control of fructolysis in primate spermatozoa. Biochim. Biophys. Acta 237, 227-238.

Lowry, O.H., Rosebrough, N.J., Farr, A.L. \& Randall, R.J. (1951) Protein measurement with the folin phenol reagent. J. biol. Chem. 193, 265-275.

Newsholme, C.A. \& Gevers, W. (1967) Control of glycolysis and gluconeogenesis in liver and kidney cortex. Vitams Horm. 25, 1-37.

Peterson, R.N. \& Freund, M. (1970) Profile of glycolytic enzyme activities in human spermatozoa. Fert. Steril. 21, $151-158$.

Peterson, R.N. \& Freund, M. (1971) Glycolysis by human spermatozoa. Levels of glycolytic intermediates. Biol. Reprod. 5, 221-227.

Racker, E. (1965) Mechanisms in Bioenergetics, p. 212. Academic Press, New York.

Wu, R. \& Racker, E. (1959) Regulatory mechanisms in carbohydrate metabolism. Limiting factors in glycoly sis of Ascites tumor cells. J. biol. Chem. 234, 1029-1035. 